\title{
Dominance of type 1 angiotensin II receptor in the nonpregnant and pregnant bovine uterus
}

\author{
K. H. Schauser, A. H. Nielsen, H. Winther, V. Dantzer and K. Poulsen \\ Department of Anatomy and Physiology, The Royal Veterinary and Agricultural University, 7 Grennegaardsvej, \\ DK-1870 Frederiksberg C, Denmark
}

\begin{abstract}
The present study was undertaken to characterize, determine and localize angiotensin II receptors in the nonpregnant and pregnant bovine uterus. In addition, the concentration of active renin, which is responsible for the generation of angiotensin, was determined. Autoradiography and angiotensin II receptor binding studies showed that all compartments of the bovine uterus contained high concentrations of angiotensin II receptors. In general, the type 1 angiotensin II receptor $\left(A_{1}\right)$ predominated over the $\mathrm{AT}_{2}$ receptor. In the endometrium, the highest density was found in the caruncles and the AT, receptor was always predominant. The density of angiotensin II receptors in the endometrium increased at the beginning of pregnancy, but decreased and reached values similar to those in nonpregnant animals near term. In the myometrium, the density of angiotensin II receptors was highest at or near the endometrial-myometrial junction. In this area, the predominant type of angiotensin II receptor in the uterus of cyclic cows varied, whereas the AT, receptor always predominated during pregnancy. Non- $\mathrm{AT}_{1}$ and non- $\mathrm{AT}_{2}$ binding sites were found in the same locations as the angiotensin II receptors, but at lower densities. With the exception of the pregnant endometrium, all compartments contained higher active renin concentrations than found in plasma, indicating local synthesis of renin. This study demonstrates a difference in the expression of types of angiotensin II receptor in the bovine uterus compared with other species. The high densities of angiotensin II receptors localized in several important areas imply that the renin-angiotensin system participates in regulation of growth and tissue function in the bovine uterus.
\end{abstract}

\section{Introduction}

A number of studies have indicated the presence of a local tissue renin-angiotensin system (RAS) in the female reproductive tract (Hagemann et al., 1994; Nielsen et al., 1995; Vinson et al., 1997). Angiotensin II synthesized locally in the tissues may be involved in the regulation of several aspects of tissue function through autocrine or paracrine actions, such as modulation of cell growth and neovascularization (Fernandez et al., 1985; Le Noble et al., 1993; Molloy et al., 1993; Stoll et al., 1995a,b; Meffert et al., 1996; Steckelings et al., 1996). The effect of angiotensin II is mediated by angiotensin II receptors, which comprise two main types, termed type 1 $\left(\mathrm{AT}_{1}\right)$ and type $2\left(\mathrm{AT}_{2}\right)$ receptors (Timmermans et al., 1993), which can be distinguished by their different affinities for non-peptide antagonists (Chiu et al., 1990; Dudley et al., 1990). Both types of receptor, as well as non-AT, and non-AT binding sites, have been demonstrated within the placenta of humans (Kalenga et al., 1996; Li et al., 1998) and cattle (Schauser et al., 1998). Within the reproductive tract, the expression of the $\mathrm{AT}_{1}$ and $\mathrm{AT}_{2}$ receptors varies significantly

Received 1 October 1998. among species and there is evidence that it changes during the oestrous cycle and pregnancy (Nielsen et al., 1995; Vinson et al., 1997). In the uterus of women with normal cyclic menstruation, a cyclic change in the angiotensin II receptor densities is observed, indicating regulation by oestrogen and progestogens (Ahmed et al., 1995; Mancina et al., 1996). Uterine angiotensin II receptor densities decrease during pregnancy and in women taking oral contraceptives (de Gasparo et al., 1994; Bing et al., 1996; Mancina et al., 1996; Matsumoto et al., 1996). Furthermore, several studies have reported downregulation of angiotensin II receptors in the pig and ovine uterus during pregnancy (Cox et al., 1993; Moeller et al., 1996; Nielsen et al., 1997).

Implantation fails in about $25 \%$ of bovine embryos (Smith et al., 1982) and about $10 \%$ of this failure is due to maternal factors (Newman et al., 1985). The uterine RAS may play a role in implantation and maintenance of pregnancy (Hagemann et al., 1994; Vinson et al., 1997). Therefore, as an extension of a recent study from this group on the expression of angiotensin II receptors in the bovine placenta (Schauser $e t$ al., 1998), an investigation was undertaken into the RAS in the nonpregnant and pregnant bovine uterus. Since renin and the ubiquitous angiotensin-converting enzyme are the 
two enzymes that are important for the synthesis of the octapeptide angiotensin II, active renin concentrations were measured in all compartments. Furthermore, expression of the angiotensin II receptor was investigated using angiotensin II receptor binding studies and autoradiography.

\section{Materials and Methods}

\section{Collection of tissues}

Uteri from nonpregnant and pregnant cows were obtained at an abattoir 20-30 min after death. A total of 27 nonpregnant cows, which had apparently normal oestrous cycles, and 38 pregnant cows were studied. The stage of oestrous cycle of the nonpregnant animals was estimated by the gross appearance of the ovary (Ireland et al., 1980; Grimes and Ireland, 1986) and the viscosity and amount of cervical and vaginal mucus. The stage of gestation was estimated by the fetal crown-rump length (Evans and Sack, 1973). A total of 10 nonpregnant animals and 25 animals at days $40-275$ of pregnancy were used for the angiotensin II receptor binding studies. Tissue samples for angiotensin II receptor binding studies were transported to the laboratory on ice (1-2h) and stored at $-20^{\circ} \mathrm{C}$. Tissue samples for autoradiography were collected from nonpregnant $(n=17)$ and pregnant animals $(n=13)$ at different days of gestation (range 50-252 days). The nonpregnant animals were grouped in oestrous period (day 1; five animals), post-oestrous period (days 2-4; four animals), dioestrous period (days 5-17; four animals) and pro-oestrous period (days 18-20; four animals). The tissue samples were snap-frozen in liquid nitrogen, wrapped in parafilm (American Can Company, Greenwich, CT) to prevent dehydration, transported on dry ice and stored at $-80^{\circ} \mathrm{C}$.

\section{Angiotensin II receptor binding studies}

Cell membrane fractions for angiotensin II receptor binding studies were prepared by homogenization of $1-2 \mathrm{~g}$ tissue in $10 \mathrm{ml}^{-1} 50 \mathrm{mmol}^{\text {Tris- }} \mathrm{HCl} \mathrm{l^{-1 }}$ ( $\mathrm{pH} \mathrm{7.4)} \mathrm{containing} 10$ mmol EDTA $\mathrm{l}^{-1}$ (Merck, Darmstadt) and $1 \mathrm{mmol}$ phenylmethylsulfonyl fluoride (PMSF) $\mathrm{l}^{-1}$ (Sigma, St Louis, MO). The homogenization was performed at $0^{\circ} \mathrm{C}$ by using the dispersing instrument, Ultra Turrax T8 (IKA Labortechnik, Staufen) at setting 3 for $30 \mathrm{~s}$, and a Potter-Elvehjem homogenizer (B. Braun, Melsungen) for $3 \mathrm{~min}$ at 250 r.p.m. The supernatant, obtained by centrifugation of the homogenate at $600 \mathrm{~g}$ for $10 \mathrm{~min}$ at $4^{\circ} \mathrm{C}$, was centrifuged at $45000 \mathrm{~g}$ for $25 \mathrm{~min}$ at $4^{\circ} \mathrm{C}$. The pellet was suspended in 10 mmol sodium phosphate $\mathrm{l}^{-1}(\mathrm{pH}$ 7.4) containing $120 \mathrm{mmol}$ sodium chloride $\mathrm{l}^{-1}, 1 \mathrm{mmol}^{\mathrm{EDTA}} \mathrm{l}^{-1}$ and $1 \mathrm{mmol} \mathrm{PMSF}^{-1}$, centrifuged at $45000 \mathrm{~g}$ for $25 \mathrm{~min}$ at $4^{\circ} \mathrm{C}$ and suspended in the same buffer with $5 \mathrm{mmol} \mathrm{MgCl}_{2} \mathrm{l}^{-1}$. These cell membrane fractions were frozen at $-20^{\circ} \mathrm{C}$ for later analysis.

The angiotensin II receptor assay was performed in duplicate, and incubation was conducted for $1 \mathrm{~h}$ at $37^{\circ} \mathrm{C}$ in a final volume of $150 \mu \mathrm{l}$. Twenty-five microlitres of [ $\left.{ }^{125} \mathrm{I}\right]\left[\mathrm{Sar}^{1}-\right.$ $\mathrm{Ile}^{5}-\mathrm{Ile}^{8}$ ]angiotensin II (specific activity $2200 \mathrm{Ci} \mathrm{mmol}^{-1}$; Du Pont, NEN Research Products, Wilmington, DE) in $10 \mathrm{mmol}$ sodium phosphate $\mathrm{l}^{-1}$ ( $\mathrm{pH} 7.4$ ) containing $120 \mathrm{mmol}$ sodium chloride $\mathrm{l}^{-1}, 1 \mathrm{mmol}$ EDTA ${ }^{-1}, 1 \mathrm{mmol}$ PMSF $1^{-1}, 5 \mathrm{mmol}$ $\mathrm{MgCl}_{2} \mathrm{l}^{-1}, 0.5 \mathrm{~g}$ soybean trypsin inhibitor type I-S $\mathrm{l}^{-1}$ (Sigma),

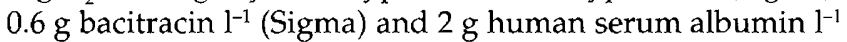
(Statens Seruminstitut, Copenhagen) was added to $100 \mu \mathrm{l}$ of the suspended cell membrane fraction. The final concentrations of $\left[{ }^{125} \mathrm{I}\right]\left[\mathrm{Sar}^{1}-\mathrm{Ile}^{5}-\mathrm{Ile}^{8}\right]$ angiotensin II was $18-52$ $\mathrm{pmol} \mathrm{l}^{-1}$. For characterization of the type of receptor, $25 \mu \mathrm{l}$ of various concentrations of losartan (DuP 753; DuPont Merck Pharmaceutical Company, Wilmington, DE) or PD 123319 ((S)-1-[[4-(dimethylamino)-3-methylphenyl]methyl]-5-(diphenylacetyl)-4,5,6,7-tetrahydro-1H-imidazo[4,5-clpyridine-6carboxylic acid, ditrifluoroacetate, monohydrate; ParkeDavis, Ann Arbor, MI) in 0.2 mol Tris- $\mathrm{HCl} \mathrm{l}^{-1}$ ( $\left.\mathrm{pH} 7.5\right)$ containing $2 \mathrm{~g}$ human serum albumin $\mathrm{l}^{-1}$ were added. The resulting displacement curves were used to determine the relative amounts of $\mathrm{AT}_{1}$ or $\mathrm{AT}_{2}$ receptors. For determination of the density of angiotensin II binding sites and their binding characteristics for [Sar $\left.{ }^{1}-\mathrm{Ile}^{5}-\mathrm{Il} \mathrm{e}^{8}\right]$ angiotensin II, $25 \mu \mathrm{l}$ of various concentrations $\left(0.1-10 \mathrm{nmol} \mathrm{l}^{-1}\right)$ of unlabelled [Sar-Ile ${ }^{5}-\mathrm{Ile}^{8}$ ]angiotensin II (Sigma) were added to the mixture of $\left.{ }^{[25} \mathrm{I}\right]\left[\mathrm{Sar}^{1}-\mathrm{Ile}^{5}-\mathrm{Ile}^{8}\right]$ angiotensin II and cell membranes. After incubation, $3 \mathrm{ml}$ ice-cold $10 \mathrm{mmol}$ sodium phosphate $\mathrm{l}^{-1}(\mathrm{pH} 7.4)$ containing $120 \mu \mathrm{mol}$ sodium chloride $\mathrm{I}^{-1}$ was added and the mixture was immediately filtered through Whatman GF/F glass fibre filters (Whatman, Clifton, NJ) that were presoaked with $2 \mathrm{~g}$ human serum albumin $\mathrm{l}^{-1}$. The filters were washed twice with $3 \mathrm{ml}$ of the same buffer and counted in a gamma counter. The specific binding was calculated by subtracting the nonspecific binding, measured in the presence of $1 \mu \mathrm{mol}$ unlabelled $\left[\mathrm{Sar}^{1}-\mathrm{Ile}^{5}-\mathrm{Ile}^{8}\right]$ angiotensin II $1^{-1}$, from the total binding. The dissociation constant $\left(K_{\mathrm{d}}\right)$ and the maximal binding capacity of ligand $\left(B_{\max }\right)$ were determined by Scatchard analysis of data obtained with unlabelled [Sar'-Ile-Ile ${ }^{8}$ ]angiotensin II, using the RADLIG program for the analysis of radio ligand binding experiments (Version 4, Biosoft, Cambridge). The binding data were best fitted with a one-site fit. The density of angiotensin II receptors was calculated using the $B_{\max }$ value and the protein concentration, assuming the binding of one molecule of ligand to each receptor.

\section{Measurement of protein concentration}

The protein concentration in cell membrane fractions was determined by the method of Lowry et al. (1951).

\section{Measurement and identification of renin}

For measurement of renin concentrations, $100 \mathrm{mg}$ tissue was homogenized in $0.5 \mathrm{ml}$ of $10 \mathrm{mmol}$ sodium phosphate $\mathrm{l}^{-1}$ (pH 7.5) containing $140 \mathrm{mmol}$ sodium chloride $\mathrm{l}^{-1}, 10 \mathrm{mmol}$ EDTA $\mathrm{l}^{-1}, 10 \mathrm{mmol}^{\mathrm{N}}$-ethylmaleimide $\mathrm{l}^{-1}$ (Sigma), $2 \mathrm{mmol}$ 8-hydroxyquinoline $\mathrm{I}^{-1}$ (Merck) and $0.3 \mathrm{mmol}$ sodium azide $\mathrm{I}^{-1}$. Homogenization was performed as described above. The homogenate was centrifuged at $1850 \mathrm{~g}$ for $15 \mathrm{~min}$ at $4^{\circ} \mathrm{C}$. The supernatant was stored at $-20^{\circ} \mathrm{C}$ before analysis.

Renin concentrations were measured using the antibody trapping method (Poulsen and Jørgensen, 1974). This 

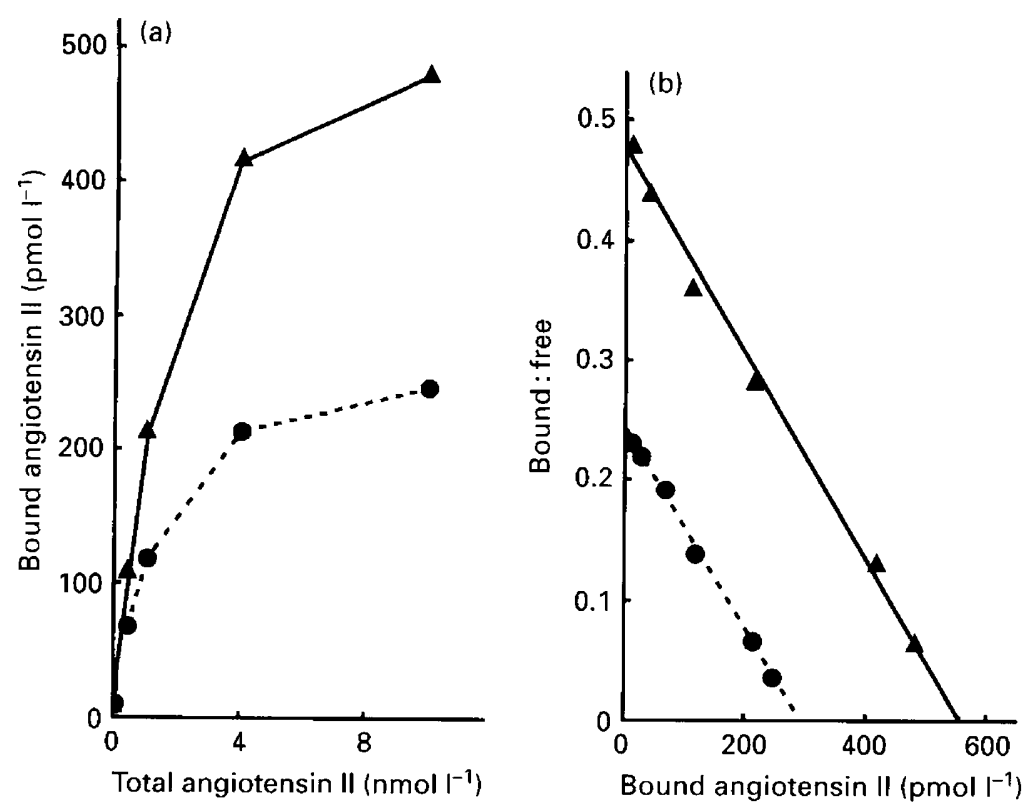

Fig. 1. (a) Representative experiments showing the specific binding of ligand with increasing concentrations of [Sar $\left.{ }^{1}-\mathrm{Ile}^{5}-\mathrm{Ile}^{8}\right]$ angiotensin II in cell membrane fractions prepared from the bovine endometrium $(\boldsymbol{O})$ and myometrium $(\boldsymbol{\Delta})$. (b) Scatchard analysis of the same data. In these experiements, the $K_{d}$ and $B_{\max }$ values were $1.20 \mathrm{nmol} \mathrm{l}^{-1}$ and $278 \mathrm{pmol} \mathrm{l}^{-1}$, respectively, in the endometrium and $1.20 \mathrm{nmol}^{-1}$ and $546 \mathrm{pmol} \mathrm{l}^{-1}$, respectively, in the myometrium.

method is described in more detail for the measurement of renin in bovine plasma and tissues (Nielsen et al., 1991, 1994; Hagemann et al., 1993). The assay was standardized against a hog renin standard (MRC, Holly Hill, London) and the renin concentrations are given as Goldblatt units (GU) per litre. Renin was identified by inhibition of its enzymic activity with $1 \mu \mathrm{mol} \mathrm{l}^{-1}$ of the specific renin inhibitor, remikiren (RO 42-5892, Hoffman-LaRoche, Basel).

\section{Autoradiography}

For in situ autoradiographic studies, a modified technique of Mendelsohn et al. (1987) was used. The samples were serial sectioned $(10 \mu \mathrm{m})$ in a cryostat at $-16^{\circ} \mathrm{C}$ and thaw-mounted on Polysine microscope slides (Menzel-Gläser, Braunschweig). The tissue sections were dried overnight at $-2^{\circ} \mathrm{C}$ and used immediately or stored at $-20^{\circ} \mathrm{C}$ for later use. Before the assay, the sections were brought to room temperature and preincubated for $15 \mathrm{~min}$ at room temperature in a buffer containing $10 \mathrm{mmol}$ sodium phosphate $\mathrm{l}^{-1}(\mathrm{pH} 7.4)$, $120 \mathrm{mmol}$ sodium chloride $\mathrm{l}^{-1}, 5 \mathrm{mmol} \mathrm{MgCl}_{2} \mathrm{l}^{-1}, 1 \mathrm{mmol}$ EGTA $\mathrm{l}^{-1}$ (Sigma), $0.3 \mathrm{mmol}$ bacitracin $\mathrm{l}^{-1}$ (Sigma) and $2 \mathrm{~g}$ proteinase-free bovine serum albumin $1^{-1}$ (Biofac $\mathrm{A} / \mathrm{S}$, Copenhagen). The sections were then incubated in a humidified chamber for $180 \mathrm{~min}$ in a fresh identical buffer containing $0.5 \mathrm{nmol}\left[{ }^{125} \mathrm{I}-\left[\mathrm{Sar}^{1}-\mathrm{Ile}^{5}-\mathrm{Ile}^{8}\right]\right.$ angiotensin II ${ }^{-1}$, a concentration close to the $K_{\mathrm{d}}$ value. Nonspecific binding was determined in serial sections using identical incubation conditions except for the addition of $1 \mu \mathrm{mol}^{-1}$ of unlabelled
[Sar ${ }^{1}-$ Ile $^{5}-$ Ile $^{8}$ ]angiotensin II. For localization and characterization of the angiotensin II receptor types, serial sections were incubated in the same buffer containing $0.5 \mathrm{nmol}\left[{ }^{125} \mathrm{I}\right]\left[\mathrm{Sar}^{1}-\mathrm{Ile}^{5}-\mathrm{Ile}^{8}\right]$ angiotensin $\mathrm{II}^{-1}$ in the presence of $5 \mu \mathrm{mol}$ losartan $\mathrm{l}^{-1}$, in the presence of $5 \mu \mathrm{mol}$ PD $123319 \mathrm{l}^{-1}$, or in the presence of both. After incubation, the sections were rinsed $4 \times 3 \mathrm{~min}$ in ice-cold $50 \mathrm{mmol}$ Tris- $\mathrm{HCl}$ $\mathrm{l}^{-1}(\mathrm{pH}$ 7.4) and then dipped in ice-cold distilled water. A stream of warm air $\left(60^{\circ} \mathrm{C}\right)$ was used to dry the sections quickly. The sections were fixed in paraformaldehyde vapours for $2 \mathrm{~h}$ at $80^{\circ} \mathrm{C}$ and allowed to evaporate over night. Thereafter, they were dipped in photographic emulsion Ilford K2 (Ilford, Brønshøj) diluted 1:2 in distilled water and exposed for 3 days at $4^{\circ} \mathrm{C}$. The developing process with Kodak D-19 developer (Kodak, Farum, Denmark) was stopped with Liquid Acid Hardener (Ilford). The slides were fixed in Rapid Fixer (Ilford) and washed for $1 \mathrm{~h}$ in rinsing water. After drying, the sections were weakly counterstained with haematoxylin and eosin to assist the localization of the silver grains. The angiotensin II receptor density was estimated by a visual subjective scoring of the silver grain deposition in the autoradiograms. The scoring was 0 (background),,+++ and +++ . Photographs were taken by using a Zeiss stereomicroscope with dark-field.

\section{Statistical analysis}

The data were analysed by non-parametric statistics (Conover, 1980), using the Stat-100 statistical analysis 


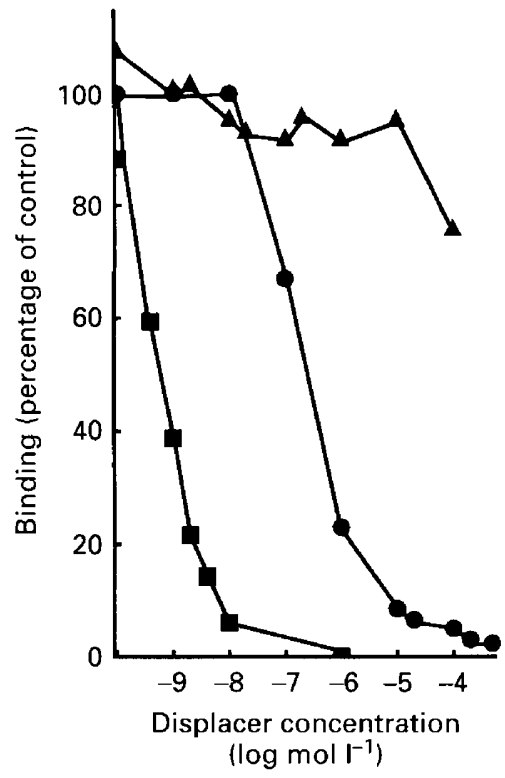

Fig. 2. Representative curves showing the displacement of the specific binding of [ $\left.{ }^{125} \mathrm{I}\right]\left[\mathrm{Sar}^{1}-\mathrm{Ile}^{5}-\mathrm{Ile}^{8}\right]$ angiotensin II by unlabelled

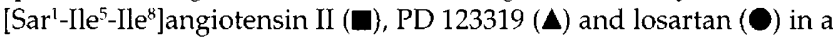
cell membrane fraction prepared from the myometrium of a cow at day 55 of pregnancy.

package (Version 1.24, Biosoft, Cambridge). Values are given as mean with the range in parentheses. $P<0.05$ was considered significant.

\section{Results}

\section{Characterization of angiotensin II receptors}

Specific binding of $\left.{ }^{125} \mathrm{I}\right]\left[\mathrm{Sar}^{1}-\mathrm{Ile}^{5}-\mathrm{Ile}^{8}\right]$ angiotensin II was found in all cell membrane fractions prepared from the bovine endometrium and myometrium. The nonspecific binding was low and unchanged during incubation at $37^{\circ} \mathrm{C}$ for $5 \mathrm{~h}(n=3)$. Equilibrium at $37^{\circ} \mathrm{C}$ was reached after $30-60$ $\min (n=3)$. The specific binding of ligand approached saturation in experiments with [ $\left.{ }^{125} \mathrm{I}\right]\left[\mathrm{Sar}^{1}-\mathrm{Ile}^{5}-\mathrm{Ile}^{8}\right]$ angiotensin II and increasing concentrations of unlabelled [Sar ${ }^{1}-$ Ile $^{5}$ Ile ${ }^{8}$ angiotensin II (Fig. 1a). The dissociation constant $\left(K_{d}\right)$ determined by Scatchard plots (Fig. 1b) was $1.08 \mathrm{nmol} \mathrm{l}^{-1}$ $\left(0.35-1.81 \mathrm{nmol} \mathrm{l}^{-1} ; n=35\right)$ in the endometrium and $0.69 \mathrm{nmol}$ $1^{-1}\left(0.27-1.38 \mathrm{nmol} \mathrm{t}^{-1} ; n=35\right)$ in the myometrium.

Curves, obtained by displacement of the specific [125I][Sar ${ }^{1}$ Ile $^{5}-I^{8} \mathrm{e}^{8}$ angiotensin II binding with the type-specific nonpeptide angiotensin II receptor antagonists, losartan (DuP 753) and PD 123319, are shown (Fig. 2). At concentrations below $10^{-6}-10^{-5} \mathrm{~mol} \mathrm{l}^{-1}$, the antagonists displace the binding type-specific (Chiu et al., 1990; Dudley et al., 1990), which allows for an estimation of the relative distribution of the two receptor types. Representative curves for the myometrium of a pregnant cow are shown (Fig. 2), together with the improving displacement curve with unlabelled [Sar ${ }^{1}-I^{5}{ }^{5}-$ Ile $^{8}$ ]angiotensin II. It was estimated that about $90 \%$ of the total angiotensin II receptors were $\mathrm{AT}_{1}$ receptors in this
Table 1. Percentage of type 1 angiotensin II receptors of the total angiotensin II receptors in the bovine uterus

\begin{tabular}{lll}
\hline & Nonpregnant cows & \multicolumn{1}{c}{ Pregnant cows } \\
\hline Endometrium & $85 \%(70-95 \%, n=7)$ & $95 \%(80-100 \%, n=9)$ \\
Myometrium & $65 \%(20-95 \%, n=8)$ & $90 \%(70-95 \%, n=9)$ \\
\hline
\end{tabular}

preparation. The percentage of $\mathrm{AT}_{1}$ receptors in the bovine uterus is shown (Table 1). There was no significant difference in the relative distribution of the angiotensin II receptor types between the endometrium and myometrium and between nonpregnant and pregnant animals (Table 1). No non- $\mathrm{AT}_{1}-$ non-AT binding sites were detected in any of the angiotensin II receptor displacement experiments.

\section{Angiotensin II receptor densities}

In the endometrium (Fig. 3), the angiotensin II receptor density was higher $(P<0.01)$ in the pregnant animals $(955$ fmol mg-1, range $115-2440 \mathrm{fmol} \mathrm{mg}^{-1}, n=25$ ) than in the nonpregnant animals $\left(375 \mathrm{fmol} \mathrm{mg}^{-1}\right.$, range $185-640 \mathrm{fmol}$ $\mathrm{mg}^{-1}, n=10$ ). There was a negative correlation between the duration of pregnancy and the receptor density (Spearman's rho $=-0.625, P<0.001$ ). In the myometrium (Fig. 4), the angiotensin II receptor density did not differ between nonpregnant (445 fmol mg-1, range $140-805 \mathrm{fmol} \mathrm{mg}^{-1}, n=10$ ) and pregnant animals (495 fmol $\mathrm{mg}^{-1}$, range $125-815 \mathrm{fmol}$ $\left.\mathrm{mg}^{-1}, n=25\right)$. There was a negative correlation between the duration of pregnancy and the receptor density (Spearman's rho $=-0.426, P<0.05)$. The angiotensin II receptor densities in the endometrium and myometrium (Figs 3 and 4) did not differ in the nonpregnant animals, whereas the densities were higher in the endometrium during pregnancy $(P<0.002)$.

\section{Renin concentrations}

The renin concentrations (Table 2) were higher in the myometrium than in the endometrium in both nonpregnant $(P<0.05)$ and pregnant animals $(P<0.001)$. In the myometrium, the renin concentration did not differ between nonpregnant and pregnant animals, whereas it was lower $(P<0.025)$ in the endometrium during pregnancy. No relationship was found between the duration of pregnancy and the renin concentrations in either the endometrium or the myometrium.

\section{Autoradiography in nonpregnant cows}

The labelling in the functional zone of the endometrial lamina propria $(n=17)$ was most dense in the caruncles and extended into the intercaruncular region, where it was concentrated in the subepithelial part (Figs 5 and 6). The AT 1 receptor was predominant. There were fewer $\mathrm{AT}_{2}$ receptors and non- $\mathrm{AT}_{1}-$ non- $\mathrm{AT}_{2}$ binding sites. The uterine epithelium showed no labelling. The basal zone revealed a moderate number of $\mathrm{AT}_{1}$ receptors and $\mathrm{AT}_{2}$ receptors, and few non- 


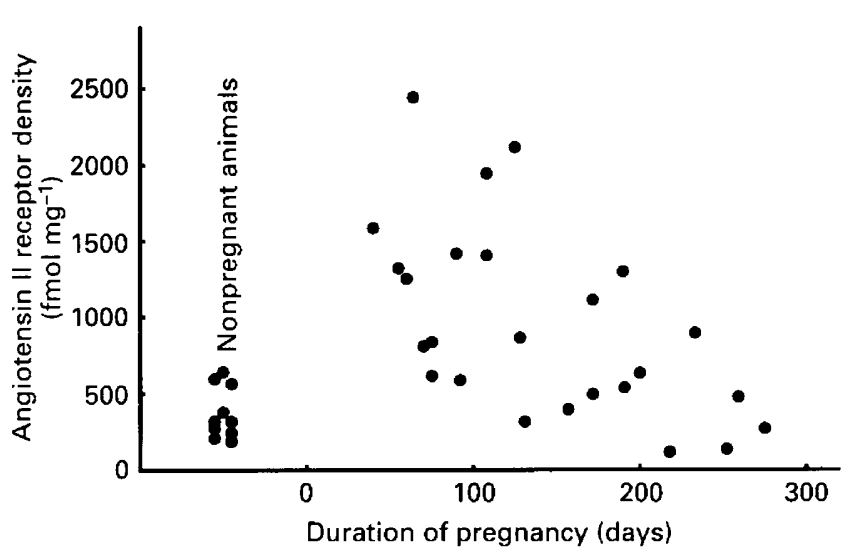

Fig. 3. Angiotensin II receptor densities in the bovine endometrium (fmol per mg cell membrane protein).

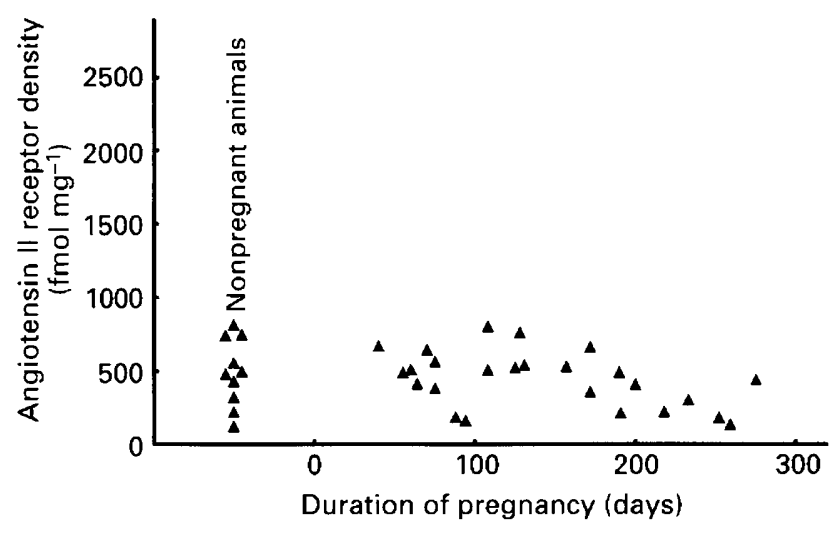

Fig. 4. Angiotensin II receptor densities in the bovine myometrium (fmol per mg cell membrane protein).

$\mathrm{AT}_{1}$-non- $\mathrm{AT}_{2}$ binding sites. In the glands and their surrounding stroma, there was a large variability with respect to binding density and receptor type expression. However, binding was always present in this area and, in general, the $\mathrm{AT}_{1}$ receptor predominated. The binding density and receptor type expression did not correlate with the stage of the oestrous cycle.

In the myometrium $(n=17)$, a very characteristic finding was the high expression of angiotensin II receptors towards the border of the endometrium (Figs 5 and 6 ). Here, the main receptor type could differ from that in the rest of the myometrium. Eight animals (four post-oestrous, one prooestrous, three oestrous) had mainly $\mathrm{AT}_{2}$ receptors (Figs $5 \mathrm{~b}$ and $6 \mathrm{~b}$ ), while five animals (two dioestrous, two prooestrous, one oestrous) showed mainly $\mathrm{AT}_{1}$ receptor binding in this area (Fig. 6d). In the external part of the myometrium, the predominant receptor type also varied. In four animals (one post-oestrous, one dioestrous, one pro-oestrous, one oestrous), the $\mathrm{AT}_{1}$ receptor was the main type (Fig. $6 \mathrm{~d}-\mathrm{f}$ ). The $\mathrm{AT}_{2}$ receptor predominated in three animals (two prooestrous, one oestrous). Most non- $\mathrm{AT}_{1}-$ non- $\mathrm{AT}_{2}$ binding sites were observed in the endometrial-myometrial junction (Figs $5 c$ and $6 c, f)$.

Binding was always present in the arteries of the
Table 2. Renin concentrations in the bovine uterus given in Goldblatt units (GU) $\mathrm{kg}^{-1}$ wet tissue mass

\begin{tabular}{lcc}
\hline & Nonpregnant cows & Pregnant cows \\
\hline Endometrium & 0.28 & 0.043 \\
& $(0.020-0.82, n=9)$ & $(0.014-0.146, n=22)$ \\
Myometrium & $\mathrm{bd}, n=1$ & $\mathrm{bd}, n=3$ \\
& 0.67 & 0.53 \\
& $(0.040-2.69, n=10)$ & $(0.063-2.14, n=25)$ \\
\hline
\end{tabular}

$n$ : number of animals; bd, below the detection limit of the renin assay $\left(0.014 \mathrm{GU} \mathrm{kg}^{-1}\right)$

endometrium and the myometrium, but the angiotensin II receptor expression varied extensively, and no cyclic scheme was apparent. In general, the $\mathrm{AT}_{1}$ receptor predominated (Fig. 6) but, in two cows, the $\mathrm{AT}_{2}$ receptor predominated and was located in the periphery of the tunica media (data not shown). In the stroma surrounding arteries, the labelling density varied greatly, with the $\mathrm{AT}_{1}$ receptor most prominently expressed.

\section{Autoradiography in pregnant cows}

The main receptor type in the uterus of the pregnant animals $(n=13)$ was the $\mathrm{AT}_{1}$ receptor. In the endometrium, the angiotensin II receptor binding was densest in the functional zone of the caruncular stalk (Figs 7 and 8). In the caruncles, the binding followed the walls of the main crypts (Fig. 8). The binding extended into the functional zone in the intercaruncular region (Fig. 7). A moderate number of $\mathrm{AT}_{2}$ receptors and few non- $\mathrm{AT}_{1}-\mathrm{non}_{-} \mathrm{AT}_{2}$ binding sites were observed in the same structures (Fig. 7). The angiotensin II receptor expression in the myometrium was similar to that in the nonpregnant cow, although the binding appeared less dense (Figs 7 and 8). In the myometrium of pregnant animals, the $\mathrm{AT}_{1}$ receptor always dominated in the endometrial-myometrial junction. In general, the arteries and the surrounding stroma showed little labelling, with the $\mathrm{AT}_{1}$ receptor as the main type (Fig. 7) but, in one cow, the $\mathrm{AT}_{2}$ receptors predominated (Fig. 8 ).

\section{Discussion}

In the bovine endometrium, the $\mathrm{AT}_{1}$ receptor predominated in nonpregnant animals. This is in agreement with findings in women, sows and the ewes (Ahmed et al., 1995; Moeller et al., 1996; Nielsen et al., 1997). The angiotensin II receptor density was increased at the beginning of the pregnancy, and reached the same density at term as in nonpregnancy. This finding differs from the findings in the pig endometrium, where the predominant $\mathrm{AT}_{1}$ receptor was downregulated throughout pregnancy (Nielsen et al., 1997). Most of the angiotensin II receptors were localized in the caruncles. In pregnancy, the caruncles are the maternal site of attachment of the placenta. The caruncles grow fast with intense angiogenesis and develop an intimate contact with the 

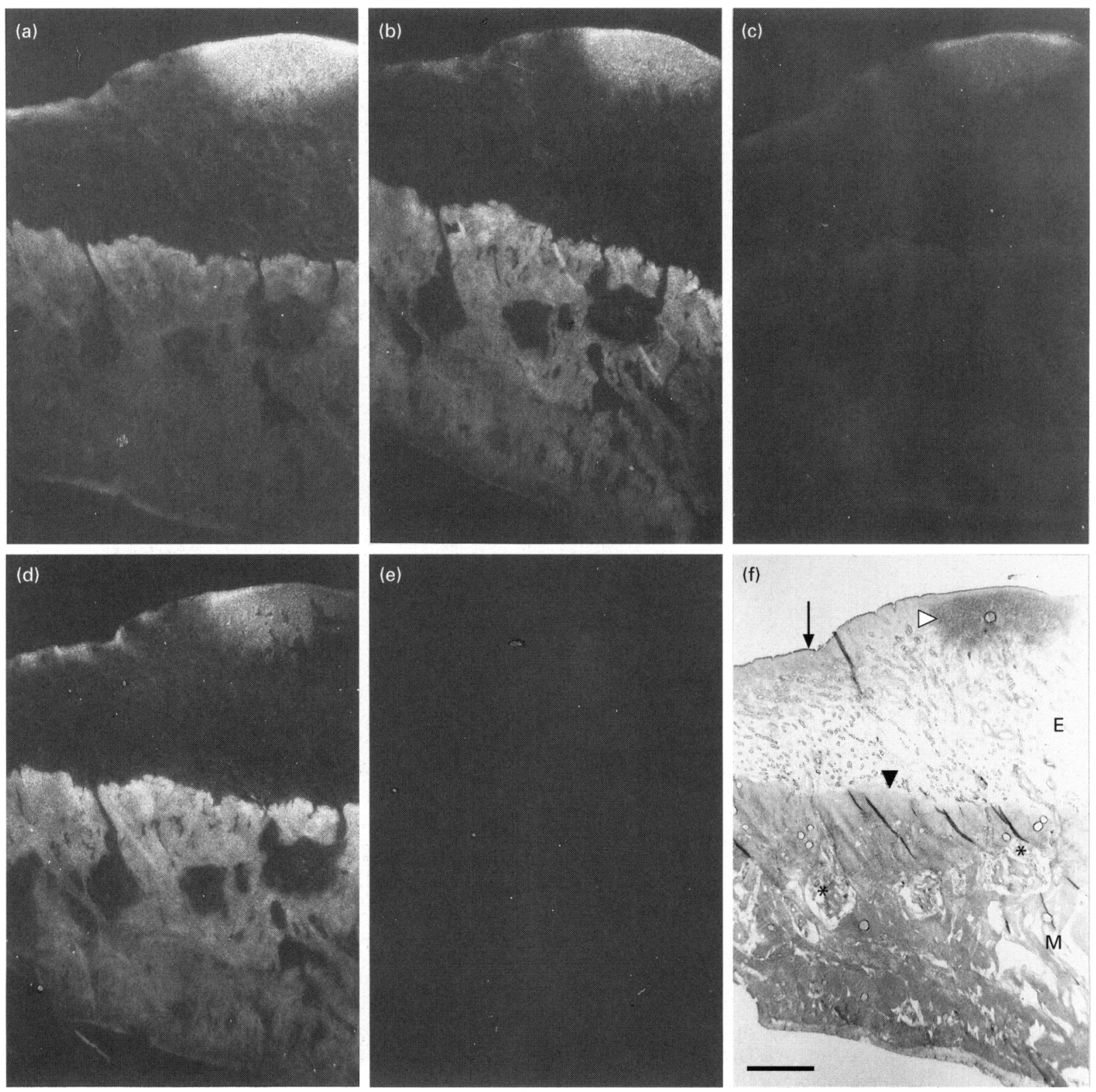

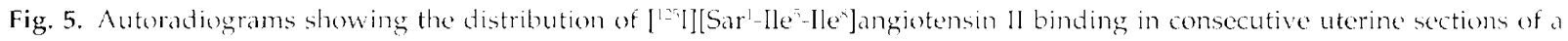
cow in dioestrus. (a) Dark-field micrograph of a section incubated in the presence of ['D 123319, showing AT, receptor binding. (b) Dark-field micrograph of section incubated in the presence of losartan, showing AT, receptor binding. (c) Dark-field micrograph of section incubated in the presence of both I'D 123319 and losartan, showing non-AT, -non-AT. binding sites. (d) Dark-field micrograph of section showing total binding. (o) Dark-field micrograph of section incubated in the presence of $1 \mu$ mol unlabelled [Sar-Ile-Ile'-angiotensin $I I \mathrm{l}^{-1}$. (f) Bright field micrograph of a section stained with haematoxylin and eosin. Arrow, luminal epithelium lining the lamina propria of the endometrium; open arrowhead, pointing from the intercaruncular region towards the caruncle; filled arrowhead, border between endometrium and myometrium; asterisks, arteries; E, endometrium; $M$, myometrium; Scale bar represents $1.6 \mathrm{~mm}$.

cotyledons of the fetal membranes. In the intercaruncular region, the most intense receptor binding was found in the functional zone of the lamina propria just beneath the luminal epithelium. No angiotensin II receptors were observed in the luminal epithelium. In contrast, the lining epithelium of the uterine glands expressed all receptor types in varying proportions, although, in general, the AT, receptor predominated. In the adjacent stroma, the $\mathrm{AT}$, receptor was a constant finding. No cyclic variation was detected.

In the bovine myometrium, the angiotensin II receptor density was highest at or near the endometrial-myometrial junction. Autoradiography in nonpregnant animals showed a large variation of angiotensin II receptor type expression in this area. The percentage of the AT, receptor varied from 20 

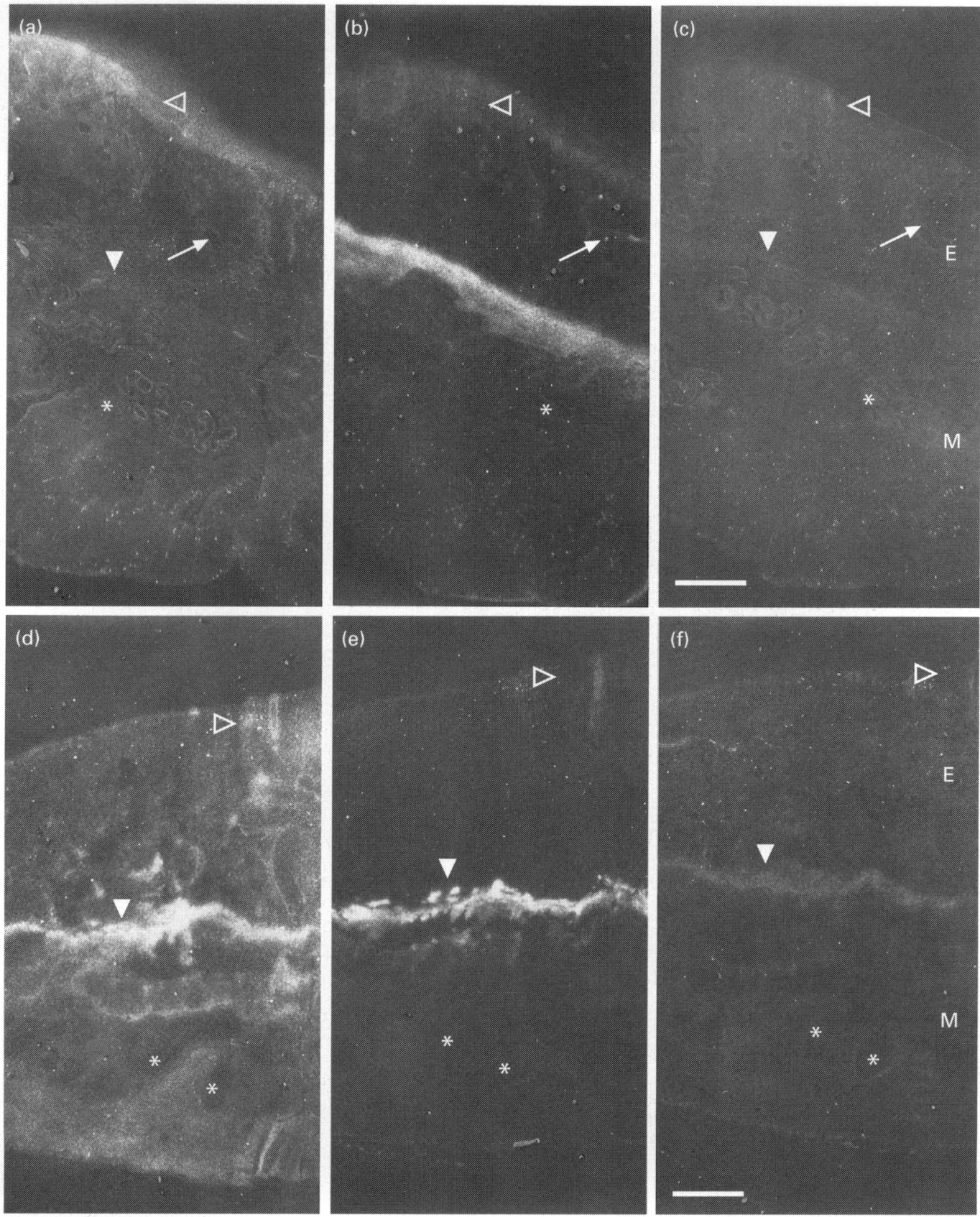

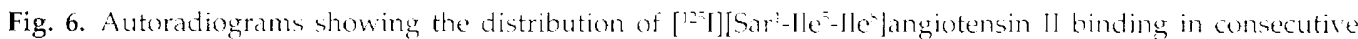
uterine sections of two cows in oestrus, showing variability in angiotensin II receptor types. (a-c) (cow l: (a) Dark-field micrograph of section incubated in the presence of PD 123319 showing AT receptor binding. (b) Dark-field micrograph of section incubated in the presence of losartan, showing AT, receptor binding. (c) Darkfield micrograph of section incubated in the presence of both l'D 123319 and losartan showing non- $\mathrm{T}_{1}-\mathrm{nom}-$ AT, binding sites. (d-f) Cow 2: (d) Dark-field micrograph of section incubated in the presence of $P$ l) 123319 showing $\mathrm{AT}$, receptor binding. (c) Dark-field micrograph of section incubated in the presence of lenartan showing $\mathrm{AT}$, receptor binding. (f) Dark-field micrograph of section incubated in the presence of $\mathrm{Pl}$ ) 123319 and of losartan showing non-AT,-non-AT, binding sites. Arrow, uterine ghands; open arrowhead, carcuncle; filled arrowhead, border between endometrium and moometrium; asterisk, arteries in mpometrium; $E$, endometrium; M, myometrium. Scale bars represent $1.2 \mathrm{~mm}$. 

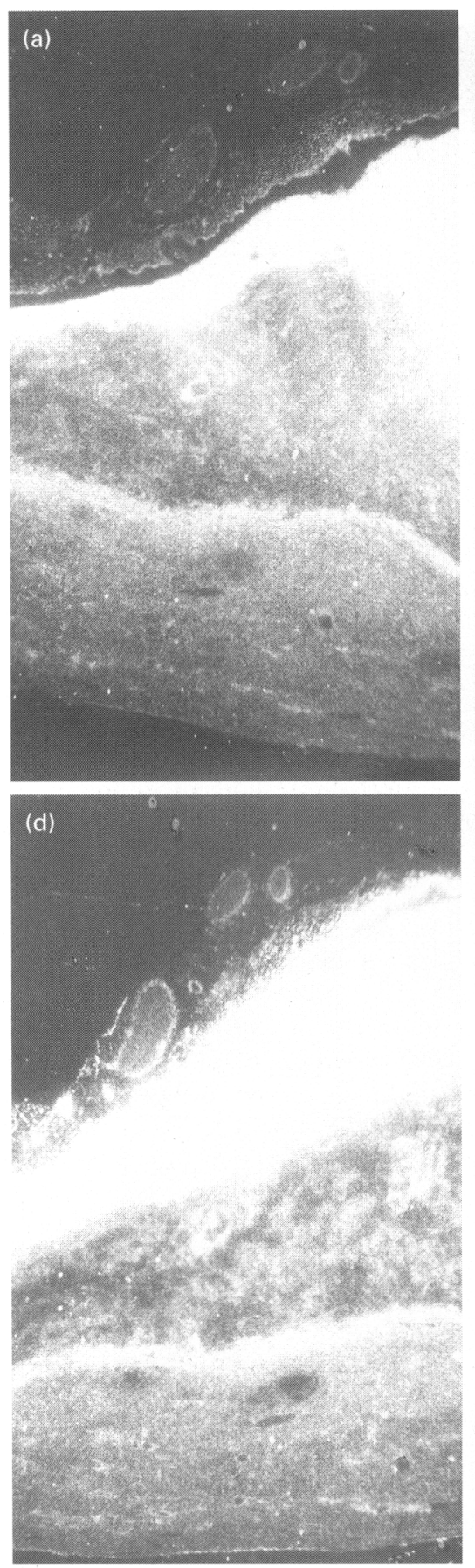
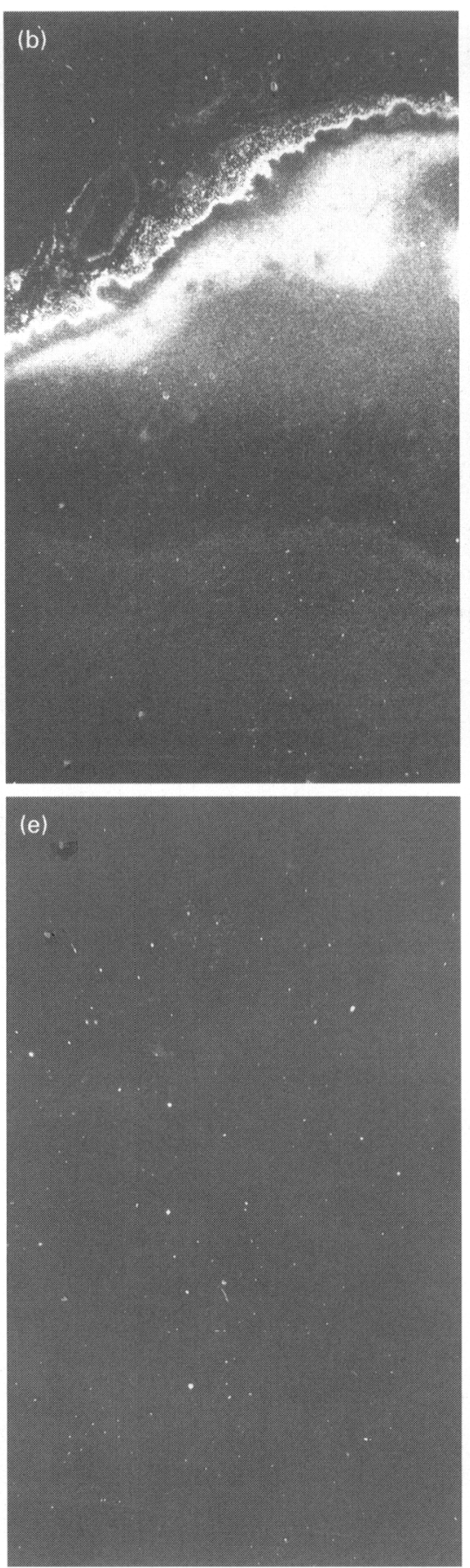
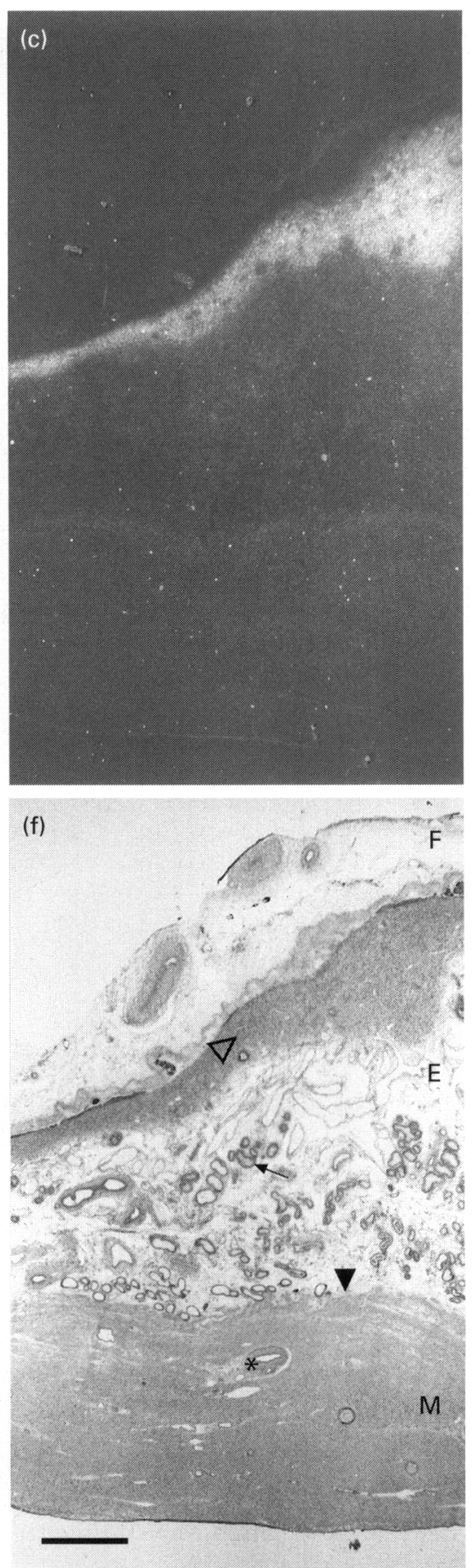

Fig. 7. Autoradiograms showing the distribution of [1-7"I][Sar-Ile--Ile ]angiotensin II binding in consecutive sections from a bovine uterus with fetal membranes (day 86) incubated with different antagonists. (a) Dark-field micrograph of section incubated in the presence of PD 123319 showing AT, receptor binding. (b) Dark-field micrograph of section incubated in the presence of losartan, showing AT, receptor binding. (c) Dark-field micrograph of section incubated in the presence of both PD 123319 and losartan, showing non-AT, non-AT binding sites. (d) Dark-field micrograph of section showing total binding. (e) Dark-field micrograph of section incubated in the presence of $1 \mu \mathrm{mol}$ unlabelled [Sar-Ile -Ile ${ }^{5}$-angiotensin II $~^{-1}$. (f) Bright field micrograph of a section stained with haematoxylin and eosin. Arrow, uterine glands; open arrowhead, pointing at caruncular stalk (placentome) to the right; filled arrowhead, border between endometrium and myometrium; asterisk, myometrial arteries; F, fetal membrane; $E$, endometrium; M, myometrium. Scale bar represents $960 \mathrm{\mu m}$. 

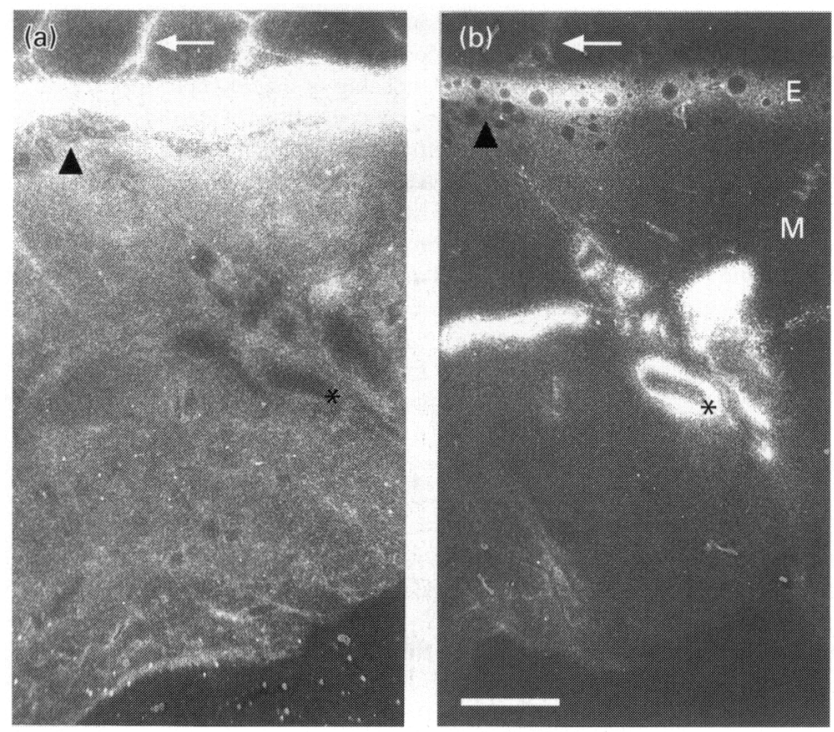

Fig. 8. Autoradiograms showing the distribution of [ $\left.{ }^{125} \mathrm{I}\right]\left[\mathrm{Sar}^{1}-\mathrm{Ile}^{5}-\right.$ $\left.\mathrm{Ile}^{8}\right]$ angiotensin II binding in consecutive sections of a bovine uterus wall, with the maternal side of the placentome at the top (day 204). (a) Dark-field micrograph of section incubated in the presence of PD 123319, showing $\mathrm{AT}_{1}$ receptor binding. (b) Dark-field micrograph of section incubated in the presence of losartan, showing $\mathrm{AT}_{2}$ receptor binding. Arrow, wall of main crypt; filled arrowhead, border of myometrium towards endometrium; asterisk, arteries; $\mathrm{E}$, endometrium at the base of a placentome; M, myometrium. Scale bar represents $1.2 \mathrm{~mm}$.

to $95 \%$ in the myometrium of these animals in the angiotensin II receptor binding studies. These findings indicate changes in the angiotensin II receptor expression during the oestrous cycle. However, the expression of the angiotensin II receptors observed during autoradiography also varied markedly among animals within the same stage of the cycle.

Throughout bovine pregnancy, the $\mathrm{AT}_{1}$ receptor type predominated. There were no significant differences in the receptor density between the nonpregnant and pregnant bovine myometrium. This finding differs markedly from the findings in other species, where the angiotensin II receptor density is downregulated during pregnancy. In sheep and pigs, a downregulation of the predominant $\mathrm{AT}_{2}$ receptor was observed in the myometrium during pregnancy (Moeller et al., 1996; Nielsen et al., 1997). In the human myometrium, Matsumoto et al. (1996) found a decrease in the predominant $\mathrm{AT}_{2}$ receptor mRNA expression during pregnancy but no changes in $\mathrm{AT}_{1}$ receptor mRNA expression. In human myometrium and its blood vessels, the predominant $\mathrm{AT}_{2}$ receptor was downregulated already during the secretory phase (Ahmed et al., 1995; Bing et al., 1996), indicating a preparation for pregnancy.

All autoradiograms, in which uterine sections were incubated with high concentrations of both PD 123319 and losartan, showed $\left.{ }^{125} \mathrm{I}\right]\left[\mathrm{Sar}^{1}-\mathrm{Ile}^{5}-\mathrm{Ile}^{8}\right]$ angiotensin II binding, indicating the presence of non- $\mathrm{AT}_{1}-$ non- $\mathrm{AT}_{2}$ binding sites. These sites were located in the same compartments as the $\mathrm{AT}_{1}$ and $\mathrm{AT}_{2}$ receptors but at much lower densities. Such novel non- $\mathrm{AT}_{1}$-non- $\mathrm{AT}_{2}$ binding sites have been observed in the human endometrium (Ahmed et al., 1995) and placenta (Li et al., 1998), and in the bovine placenta and fetal membranes (Schauser et al., 1998). The nature of these binding sites is still unknown.

The active renin concentrations in the nonpregnant and pregnant myometrium did not differ. In the nonpregnant endometrium, the active renin concentrations were lower than in the myometrium and decreased further during pregnancy. This finding is in contrast to findings in pigs, in which endometrial renin concentrations remained unchanged (Hagemann et al., 1993). In humans and all other animals investigated, renin increased in the uterus during pregnancy (Hagemann et al., 1994). Except for the pregnant bovine endometrium, the active renin concentrations were higher than those found earlier in bovine plasma (Nielsen $c t$ al., 1991). This finding indicates local synthesis of active renin, in agreement with a previous study in the human endometrium (Johnson, 1980).

In contrast to the abundant expression of the $\mathrm{AT}_{2}$ receptor type during fetal development, $\mathrm{AT}_{2}$ receptor is expressed in few tissues in adult life. The ovary and the uterus express the $\mathrm{AT}_{2}$ receptor extensively in adults (Ahmed et al., 1995; Nielsen et al., 1995, 1997) indicating an important role in reproduction. In the bovine placenta, the angiotensin II receptors were predominantly $\mathrm{AT}_{2}$ in the fetal and $\mathrm{AT}_{1}$ in the maternal compartment (Schauser et al., 1998). The distribution of the angiotensin II receptors did not change throughout gestation. The high expression of angiotensin II receptors in the bovine placenta and fetal membranes indicates an effect on regulatory as well as growth processes in these tissues (Schauser et al., 1998). In the bovine uterus, the two angiotensin II receptor types were located in the same compartments but in variable proportions. A growthpromoting effect of angiotensin II has been shown to be mediated by the $\mathrm{AT}_{1}$ receptor (Stoll et al., 1995a). In endothelial cells, this effect was counteracted by the antiproliferative actions of the $\mathrm{AT}_{2}$ receptor (Stoll et al., 1995a,b; Meffert et al., 1996). In a culture of human keratinocytes, angiotensin II stimulated proliferation via non-AT - non- $\mathrm{AT}_{2}$ binding sites (Steckelings et al., 1996). These findings indicate that angiotensin II plays a role as a growth factor. Cross-talk between the $\mathrm{AT}_{1}$ and $\mathrm{AT}_{2}$ receptors, and perhaps even between the non- $\mathrm{AT}_{1}-$ non- $\mathrm{AT}_{2}$ angiotensin II binding sites, may act as a modulator of the effect of angiotensin II (Gelband et al., 1997; Li et al., 1998).

Angiotensin II is a potent systemic vasoconstrictor, and its effect is exerted via the AT, receptor but is less pronounced in human and ovine uterine arteries (Maigaard et al., 1986). It is likely that angiotensin II also modulates and regulates vascular resistance and blood flow in the bovine uterus, since $\mathrm{AT}_{1}$ receptors were found in the tunica media of the arteries. Although the expression often appeared very weak, a marked effect is possible. The $\mathrm{AT}_{2}$ receptor dominated in the human uterine arteries and was downregulated during pregnancy (Cox et al., 1996). The $\mathrm{AT}_{2}$ receptor was predominant in the arteries of only 3 of 30 bovine uteri.

The $\mathrm{AT}_{1}$ receptor is known to mediate contraction of the myometrium (Maigaard et al., 1986; Odum and Broughton, 1988). Nonpregnant women did not respond to angiotensin 
II, whereas there was a response in pregnant and labouring women (Cox et al., 1996).

Angiotensin II was shown to increase vascular permeability (Robertson and Khairallah, 1972) and to possess angiogenic properties (Fernandez et al., 1985, Le Noble et al., 1993). The high densities of angiotensin II receptors in the caruncles, especially in the beginning of the pregnancy, indicate that angiotensin II plays a role in implantation, the subsequent vascular development and in the maintenance of pregnancy.

In conclusion, all parts of the bovine uterus contained high densities of angiotensin II receptors. In general, the $\mathrm{AT}_{1}$ receptor predominated in all compartments. In the endometrium, the highest density was found in the caruncles. The endometrial angiotensin II receptor density was increased at the beginning of pregnancy but decreased and, near term, reached a density similar to that observed during nonpregnancy. In the myometrium, the angiotensin II receptor density was highest at or near the endometrialmyometrial junction. High active renin concentrations were found in all compartments but, in the endometrium, it was low during pregnancy. Further studies of the uterine compartments expressing angiotensin II receptors are needed to elucidate the role of angiotensin II in the uterus of the cyclic and pregnant cows.

The skilful technical assistance of S. Holm, C. T. Larsen and I. Thomsen is gratefully acknowledged. The renin inhibitor remikiren (RO 42-5892) was kindly provided by W. Fischli, Hoffman-LaRoche, Basel, Switzerland. The non-peptide type-specific angiotensin II receptor antagonists losartan (DuP 753) and PD 123319 were gifts from the Du Pont Merck Pharmaceutical Company, Wilmington, DE and Parke-Davis, Ann Arbor, MI, respectively.

\section{References}

Ahmed A, Li XF, Shams M, Gregory J, Rollason T, Barnes NM and Newton IR (1995) Localization of the angiotensin II and its receptor subtype expression in human endometrium and identification of a novel highaffinity angiotensin II binding site Journal of Clinical Investigation 96 848-857

Bing C, Johnson IR and Pipkin FB (1996) Angiotensin receptors in myometrium and myometrial vessels from uteri of women during the follicular and luteal phases of the menstrual cycle and in late pregnancy Clinical Science 90 499-505

Chiu AT, McCall DE, Ardecky RJ, Duncia JV, Nguyen TT and Timmermans PB (1990) Angiotensin II receptor subtypes and their selective nonpeptide ligands. In Receptor pp 33-40 Ed. G Litwack. The Humana Press, Clifton

Conover WJ (1980) Practical Non-Parametric Statistics 2nd edn. John Wiley, New York

Cox BE, Ipson MA, Shaul PW, Kamm KE and Rosenfeld CR (1993) Myometrial angiotensin II receptor subtypes change during ovine pregnancy Journal of Clinical Investigation 92 2240-2248

Cox BE, Word RA and Rosenfeld CR (1996) Angiotensin II receptor characteristics and subtype expression in uterine arteries and myometrium during pregnancy Journal of Clinical Endocrinology and Metabolism 81 49-58

de Gasparo M, Whitebread S, Kalenga MK, De Hertogh R, Crevoisier P and Thomas K (1994) Downregulation of the angiotensin II receptor subtype $\mathrm{AT}_{2}$ in human myometrium during pregnancy Regulatory Peptides 53 39-45

Dudley DT, Panek RL, Major TC, Lu GH, Bruns RF, Klinkefus BA, Hodges JC and Weishaar RE (1990) Subclasses of angiotensin II binding sites and their functional significance Molecular Pharmacology 38 370-377

Evans HE and Sack WO (1973) Prenatal development of domestic and laboratory mammals: growth curves, external features and selected references Zentralblatt fïr Veterinärmedizin, Reihe C $211-45$

Fernandez LA, Twickler J and Mead A (1985) Neovascularization produced by angiotensin II Journal of Laboratory and Clinical Medicine 105 141-145

Gelband CH, Zhu M, Lu D, Reagan LP, Fluharty SJ, Posner P, Raizada MK and Sumners $C$ (1997) Functional interaction between neuronal $\mathrm{AT}_{1}$ and $\mathrm{AT}_{2}$ receptors Endocrinology 138 2195-2198

Grimes RW and Ireland JJ (1986) Relationship of macroscopic appearance of the surface of bovine ovarian follicles, concentrations of steroids in follicular fluid, and maturation of oocytes in vitro. Biology of Reproduction 35 725-732

Hagemann A, Dantzer V, Nielsen AH and Poulsen K (1993) Renin and prorenin in reproductive tissues during gestation in pigs and cattle Clinical and Experimental Pharmacology and Physiology 20 41-50

Hagemann A, Nielsen AH and Poulsen K (1994) The uteroplacental renin-angiotensin system: a review Experimental and Clinical Endocrinology 102252-261

Ireland JJ, Murphee RL and Coulson PB (1980) Accuracy of predicting stages of bovine estrous cycle by gross appearance of the corpus luteum Journal of Dairy Science 63 155-160

Johnson IR (1980) Renin substrate, active and acid-activatable renin concentrations in human plasma and endometrium during the normal menstrual cycle British Journal of Obstetrics and Gynaecology 87 875-882

Kalenga MK, de Gasparo M, Thomas K and De Hertogh R (1996) Downregulation of angiotensin $\mathrm{AT}_{1}$ receptor by progesterone in human placenta Journal of Clinical Endocrinology and Metabolism 81 998-1002

Le Noble FAC, Schreurs NHJS, Van Straaten HWM, Slaaf DW, Smits JFM, Rogg H and Struijker-Boudier HAJ (1993) Evidence for a novel angiotensin II receptor involved in angiogenesis in chick embryo chorioallantoic membrane American Journal of Physiology 264 R460-R465

Li X, Shams M, Zhu J, Khalig A, Wilkes M, Whittle M, Barnes $N$ and Ahmed A (1998) Cellular localization of $\mathrm{AT}_{1}$ receptor $\mathrm{mRNA}$ and protein in normal placenta and its reduced expression in intrauterine growth restriction Journal of Clinical Investigation 101 442-454

Lowry OH, Rosebrough NJ, Farr AL, and Randall RJ (1951) Protein measurement with the folin phenol reagent Journal of Biological Chemistry $193265-275$

Maigaard S, Forman A, and Andersson KE (1986) Differential effects of angiotensin, vasopressin and oxytocin on various smooth muscle tissues within the human uteroplacental unit Acta Physiologica Scandinavia 128 23-31

Mancina R, Susini T, Renzetti A, Forti G, Razzoli E, Serio M and Maggi M (1996) Sex steroid modulation of $\mathrm{AT}_{2}$ receptors in human myometrium Journal of Clinical Endocrinology and Metaboism 81 1753-1757

Matsumoto T, Sagawa N, Mukoyama M, Tanaka I, Itoh H, Goto M, Horiuchi M, Dzau VJ, Mori T and Nakao K (1996) Type 2 angiotensin II receptor is expressed in human myometrium and uterine leiomyoma and is downregulated during pregnancy Journal of Clinical Endocrinology and Metabolism 81 4366-4372

Meffert S, Stoll M, Steckelings UM, Bottari SP and Unger T (1996) The angiotensin II $\mathrm{AT}_{2}$ receptor inhibits proliferation and promotes differentiation in PC12W cell Molecular and Cellular Endocrinology 122 59-67

Mendelsohn FA, Millan M, Quirion R, Aguilera G, Chou ST and Catt KJ (1987) Localization of angiotensin II receptors in rat and monkey kidney by in vitro autoradiography Kidney International 31 Supplement 20 S40-S44

Moeller I, Chai SY, MacGregor DP, Aldred GP and Mendelsohn FA (1996) Localization and quantitation of angiotensin $\mathrm{AT}_{1}$ and $\mathrm{AT}$, receptors in the pregnant and non-pregnant sheep uterus Regulatory Peptides 61 213-218

Molloy CJ, Taylor DS and Weber H (1993) Angiotensin II stimulation of rapid protein tyrosine phosphorylation and protein kinase activation in rat aortic smooth muscle cells Journal of Biological Chemistry 268 7338-7345

Newman S, Harris DL and Doolittle DP (1985) Lifetime parental productivity in twenty-seven crosses of mice II. Weaning traits reflecting reproduction and lactation Journal of Animal Science 61 367-375

Nielsen AH, Gotfredsen P, Nielsen PB, Hyttel P and Poulsen K (1991) Measurement of renin and prorenin in cattle, hog and horse Comparative Biochemistry and Physiology A $100127-131$

Nielsen AH, Hagemann A, Svenstrup B, Nielsen J and Poulsen K (1994) Angiotensin II receptor density in bovine ovarian follicles relates to tissue renin and follicular size Clinical and Experimental Pharmacology and Physiology 21 463-469

Nielsen AH, Hagemann A and Poulsen K (1995) The tissue renin-angiotensin system in the female reproductive tissues: a review Advances in Experimental Medicine and Biology 377 253-268

Nielsen AH, Schauser K, Winther H, Dantzer V and Poulsen K (1997) Angiotensin II receptors and renin in the porcine uterus: myometrial $\mathrm{AT}_{2}$ and endometrial $\mathrm{AT}_{1}$ receptors are downregulated during gestation Clinical and Experimental Pharmacology and Physiology 24 309-314

Odum CU and Broughton PF (1988) Studies on the effects of nitrendipine on oxytocin-, angiotensin II- and ergometrine-induced contraction of pregnant 
human myometrium in vitro. British Journal of Obstetrics and Gynaecology 95 765-770

Poulsen K and Jergensen J (1974) An easy radioimmunological microassay of renin activity, concentration and substrate in human and animal plasma and tissues based on angiotensin I trapping by antibody Journal of Clinical Endocrinology and Metabolism 39 816-825

Robertson AL and Khairallah PA (1972) Effects of angiotensin II and some analogues on vascular permeability in the rabbit Circulation Research 31 923-931

Schauser KH, Nielsen AH, Winther H, Dantzer V and Poulsen K (1998) Autoradiographic localization and characterization of angiotensin II receptors in the bovine placenta and fetal membranes Biology of Reproduction 59 684-692

Smith MF, Nix KJ, Kraemer DC, Amoss MS, Herron MA and Wiltbank JN (1982) Fertilization rate and early embryonic loss in Brahman crossbred heifers Journal of Animal Science 54 1005-1011
Steckelings UM, Artuc M, Paul M, Stoll M and Henz BM (1996) Angiotensin II stimulates proliferation of primary human keratinocytes via a non-AT, non- $\mathrm{AT}_{2}$ angiotensin receptor Biochemical and Biophysical Research Communications 229 329-333

Stoll M, Meffert S, Stroth U and Unger T (1995a) Growth or antigrowth: angiotensin and the endothelium Journal of Hypertension 13 1529-1534

Stoll M, Steckelings UM, Paul M, Bottari SP, Metzger R and Unger T (1995b) The angiotensin $\mathrm{AT}_{2}$-receptor mediates inhibition of cell proliferation in coronary endothelial cells Journal of Clinical Investigation 95 651-657

Timmermans PB, Wong PC, Chiu AT, Herblin WF, Benfield P, Carini DJ, Lee RJ, Wexler RR, Saye JA and Smith RD (1993) Angiotensin II receptors and angiotensin II receptor antagonists Pharmacological Reviews 45 205-251

Vinson GP, Saridogan E, Puddefoot JR and Djahanbakhch O (1997) Tissue renin-angiotensin systems and reproduction: a review Human Reproduction $12651-662$ 